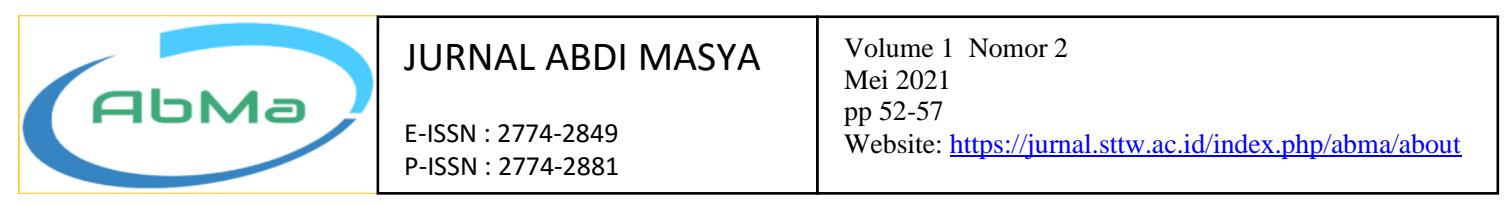

\title{
PEMBUATAN HANDWASHER RUANGAN SISTEM OTOMATIS PADA MASYARAKAT
}

\section{APPLICATED INDOOR AUTOMATIC HANDWASHER TO PUBLIC}

\author{
Joko Yunianto Prihatin ${ }^{1 *}$, Slamet Pambudi ${ }^{2}$, Heri Kustanto ${ }^{3}$, Yoga edwin ${ }^{4}$, Adam Adi \\ Pamungkas $^{5}$
}

\author{
1,2,3,4,5Sekolah Tinggi Teknologi Warga Surakarta, Surakarta, Indonesia \\ *Email: jokoyp.atw@gmail.com
}

\begin{abstract}
ABSTRAK
Generasi muda karang taruna harus selaras dengan 10 program yang dimiliki oleh PKK ini dapat terlaksana dengan tepat sasaran, yaitu penghayatan dan pengalaman pancasila, gotong royong, pangan, sandang, perumahan dan tata laksana rumah tangga, pendidikan dan keterampilan, kesehatan, pengembangan kehidupan berkoperasi, kelestarian lingkungan hidup dan perencanaan sehat. Perpres No.99, 2017. Tujuan dari kegiatan pengabdian masyarakat ini adalah untuk mampu mencegah meluasnya penyebaran virus corona di wilayah Kelurahan Kratonan dengan program gemar cuci tangan dengan air mengalir di setiap waktu. Metode yang diterapkan adalah dengan pembuatan alat automatic indoor handwasher sistem portable dan hemat listrik. Hasil dari kegiatan ini adalah bahwa alat handwasher tersebut sering digunakan di pendopo kelurahan kratonan, sehingga mampu meningkatkan produktifitas kegiatan kemasyarakatan terutama PKK dan Kti menuju kemandirian kampung sehat. Disamping itu kegiatan ini mampu menciptakan teknik lebih baik dalam pengelolaan media fluida air sebagai sumber kehidupan sehat.
\end{abstract}

Kata Kunci : air mengalir, handwasher, portable.

\begin{abstract}
The young generation of youth organizations must be in line with the 10 programs owned by the $P K K$ to be carried out with the right target, appreciation, and experience of Pancasila, cooperation, food, clothing, housing, and household management, education and skills, health, development of cooperative life, environmental sustainability and healthy planning.PerPres, No.99, 2017. The purpose of this community service activity is to be able to prevent the spread of the coronavirus in the Kratonan Village area with a program of fond of washing hands with running water at any time. The method applied is to manufacture a portable automatic indoor hand-washer system that saves electricity. The result of this activity is that the hand-washer is often used in the pavilion of the Kratonan village, to be able to increase the productivity of community activities, especially PKK and Kti towards healthy village independence. Besides, this activity can create better techniques in the management of water fluid media as a source of healthy life
\end{abstract}

Keywords: water flow, hand-washer, portable.

\section{Submit : 9 Maret $2021 \quad$ Accepted: 28 April 2021}

Published: 28 Mei 2021 


\section{PENDAHULUAN}

Wilayah Kelurahan Kratonan Kota Surakarta terdiri dari 6 rukun warga dengan berlokasi berbatasan sebelah selatan kelurahan serengan, sebelah barat kelurahan tipes, sebelah utara kelurahan jayengan dan sebelah timur kelurahan gajahan pasar kliwon.

Generasi muda karang taruna dan ibu - ibu PKK Kelurahan Kratonan dihadapkan dengan tantangan untuk mampu mencegah meluasnya penyebaran virus corona di wilayah tersebut. Sehingga 10 program yang dimiliki oleh PKK ini dapat terlaksana dengan tepat sasaran, yaitu penghayatan dan pengalaman pancasila, gotong royong, pangan, sandang, perumahan dan tata laksana rumah tangga, pendidikan dan keterampilan, kesehatan, pengembangan kehidupan berkoperasi, kelestarian lingkungan hidup dan perencanaan sehat. Perpres No.99, 2017 [1].

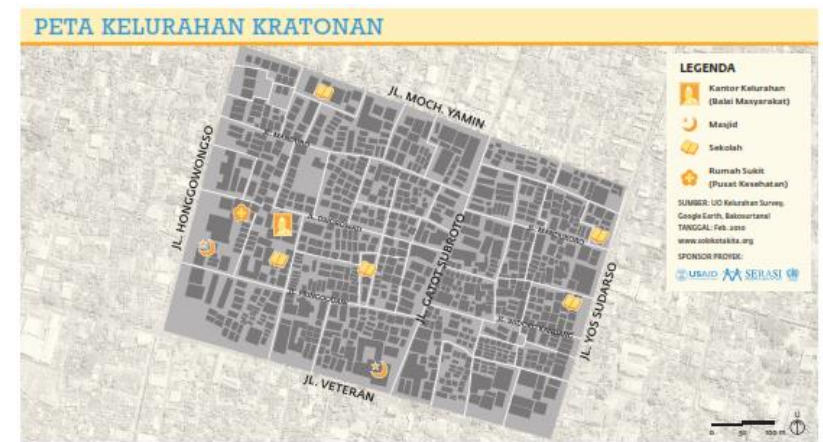

Gambar 1. peta wilayah kelurahan kratonan kecamatan serengan kota surakarta

WHO, 2010 [2], cuci tangan adalah suatu prosedur atau tindakan membersihkan tangan dengan menggunakan sabun dan air yang mengalir atau Hand Rub dengan antiseptik (berbasis alkohol). Bisa diartikan mencuci tangan merupakan teknik dasar yang paling penting dalam pencegahan dan pengontrolan infeksi.

Permasalahan yang ditimbulkan dari pengelolaan Karang Taruna dan PKK di masyarakat kelurahan kratonan ini adalah belum adanya penertiban secara terkendali gerakan gemar mencuci tangan oleh semua warga.

Berdasarkan penjelasan pengelola karang taruna kelurahan kratonan bahwa proses mencuci tangan oleh warga masih sangat terbatas dan rawan penyebaran virusnya di pegangan krannya tersebut. Disatu sisi air pancaran yang dikeluarkan tidak bisa menyebar dan hanya bertekanan terpusat yang membuat sulit pemerataan ketika mencuci tangan hingga bersih seperti dijelaskan pada gambar 2 dibawah ini.
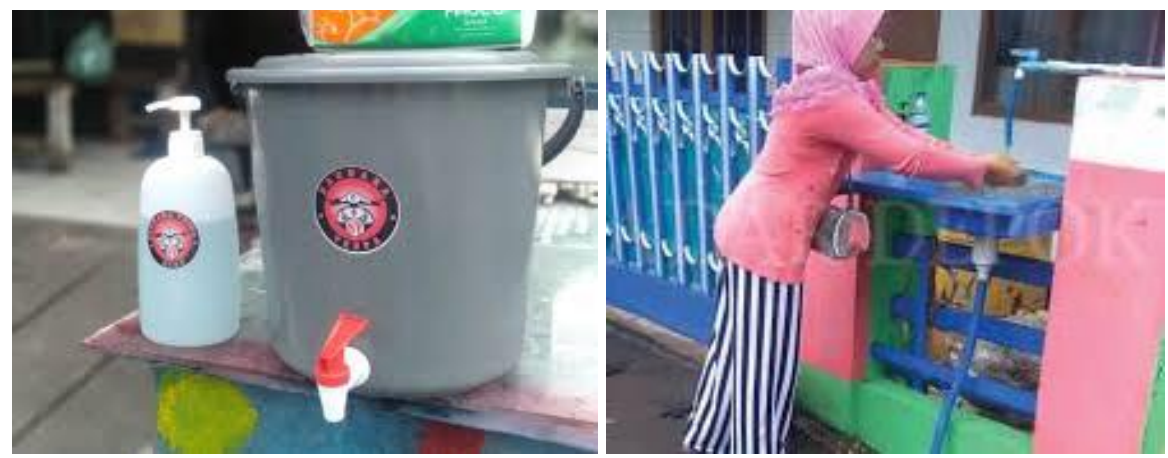

Gambar 2. permasalahan proses mencuci tangan warga masyarakat 
Permasalahan diatas yang menjadi dasar latar belakang dan, selanjutnya pelaksanaan kegiatan pengabdian masyarakat ini berupa pembuatan alat cuci tangan otomatis dalam ruangan. Alat tersebut bertujuan untuk untuk mengaktifkan gerakan masyarakat gemar mencuci tangan menuju kemadirian kesehatan dan kebersihan.

\section{METODE}

Pelaksanakan kegiatan pengabdian di mitra PKK dan Karang Taruna Kelurahan Kratonan Surakarta, sedangkan pengujian dan pembuatan mesin dilaksanakan oleh tim pengabdian Sekolah Tinggi Teknologi Warga Surakarta. pada bulan Agustus tahun 2020 sampai bulan januari tahun 2021. Pelaksanaan kegiatan pengabdian tersebut dijelaskan pada gambar 3 diagram alir dibawah ini.

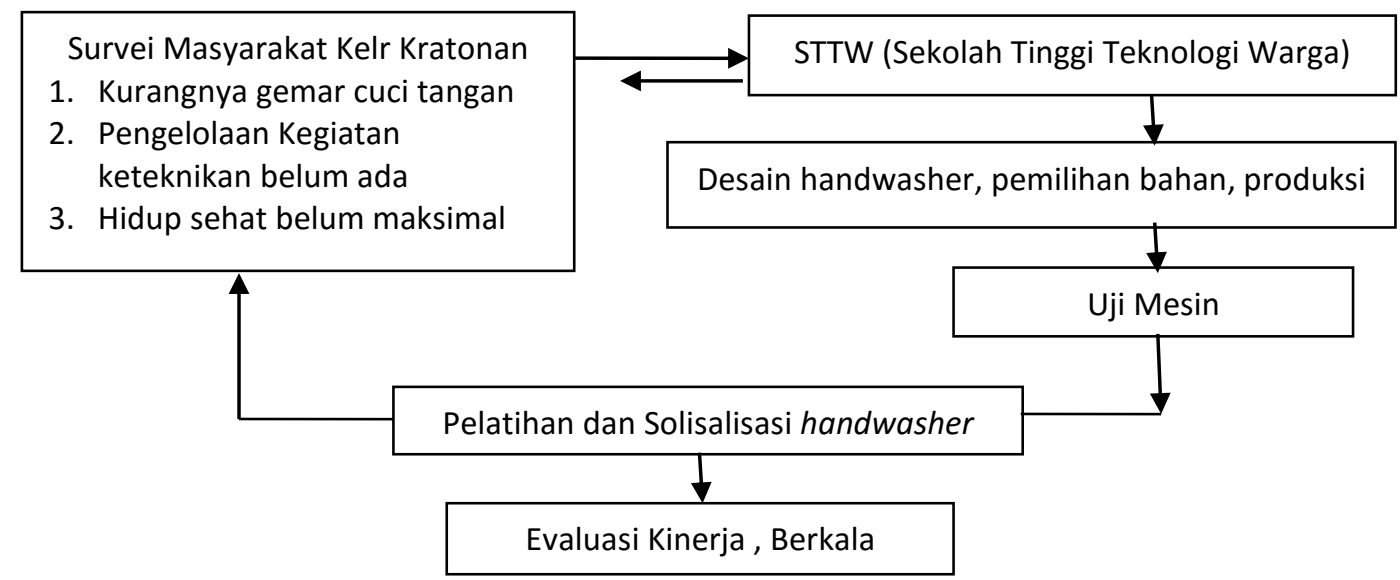

Gambar 3. Diagram alir pengabdian handwasher otomatis

Adapun beberapa langkah yang dilaksanakan oleh tim pelaksana P2M dalam mengatasi permasalahan di atas adalah :

1. Dilakukan survei dan tanya jawab ke organisasi PKK dan Kti kelurahan kratonan, guna mendapatkan informasi dan mengidentifikasi permasalahan cuci tangan.

2. Tim pelaksana mengadakan pembuatan konsep awal yang selanjutnya dilakukan pembahasan bersama berupa draft, spesifikasi bahan dan alat.

3. Membuat konsep jadi dan membuat kesepakatan pelaksanaan kegiatan dan pembagian tugas tanggungjawabnya.

4. Membangun mesin sesuai dengan spesifikasi yang dibutuhkan.

5. Dilakukan pengujian alat (kapasitas produksi, pengoperasian, perawatan)

6. Pelaksanaan sosialisasi, pelatihan dalam pengoperasian dan perawatan mesin tersebut.

7. Evaluasi kinerja alat ke Kti dan PKK secara berkala.

Evaluasi dan pemantauan lanjut, sehingga permasalahan dan batasan kemampuan mesin bisa terkontrol secara langsung. Pemantauan yang dilakukan secara bertahap, mulai dari periodik pemakaian, bertahap, dan sampai konfirmasi melalui telepon.

Pengelolaan Kegiatan

Dalam pengelolaan kegiatan ini, tim pelaksana tidak mengalami masalah mengingat lokasi mitra masih dalam satu wilayah Kabupaten Surakarta dan tidak jauh dari kampus Sekolah Tinggi Teknologi Warga Surakarta. Dalam merancang bangun alat handwasher otomatis ini dilakukan di laboratorium perkakas dan laboratorium fluida 
Sekolah Tinggi Teknologi Warga Surakarta. Selanjutnya untuk pengujian alat dilakukan dengan sesuai dengan standar yang ditetapkan.

\section{Pemantauan dan Indikator Hasil Kinerja}

Keberhasilan program kegiatan ini ditinjau dan bersudut pandang pada indikator keberhasilan dari beberapa segi antara lain: Segi manajemen mampu menjadikan kegiatan kebiasaan gemar mencuci tangan yang penuh dengan kesadaran. Sehingga koordinasi antar pengelola dan masyarakat pelaku dalam pelaksanaan kegiatan tersebut menjadi lebih bersemangat. Kualitas bahan dan produk yang dihasilkan lebih aman, karena terbuat dari bahan tidak tajam dan tidak mudah berkaran. Disamping itu juga dilengkapi dengan keunggulan sensor gerak yang mampu mengalirkan air tanpa menyentuh kran.

Menurut E.C. Halim [3], faktor dalam bentuk fasilitas yang sudah baik, tetapi jumlahnya masih belum mencukupi. Faktor penguat dorongan guru untuk melakukan CTPS dan motivasi lingkungan yang terkait dengan tangan yang kotor dapat menyebabkan pengalaman sakit yang telah dialami dan terbiasa dengan CTPS. Kesimpulan yang dapat ditarik adalah bahwa semua informan memiliki beragam perilaku dan risiko terhadap kesehatan mereka. Perilaku malas adalah kunci utama yang harus dilawan agar tidak mengganggu kesehatan. G.Danel [4] menyatakan bahwa suatu sistem keran dispenser dirancang otomatis berbasis mikrokontroler AT89S52. Pada sistem ini, keran akan terbuka ketika cahaya dari LED ke fotodioda (yang terpisah sejauh $16 \mathrm{~cm}$ ) terhalang oleh cangkir atau tangan. Air akan mengalir ke dalam cangkir melalui keran dan berhenti secara otomatis ketika jarak antara sensor ultrasonik dan permukaan air mencapai $5 \mathrm{~cm}$. menurut A.H.P. Mawuntu [5], prosedur cuci tangan dan lamanya cuci tangan dengan air mengalir perlu dimodifikasi dengan memperlama waktu cuci tangan dan memberi perhatian khusus pada daerah sela-sela jari dan punggung tangan sehingga mempengaruhi efikasi.

\section{HASIL DAN PEMBAHASAN}

Luaran hasil kegiatan pengabdian ini berupa alat automatic indoor handwasher. Desain dan hasil mesin yang dicapai dapat dijelaskan pada gambar dibawah ini.

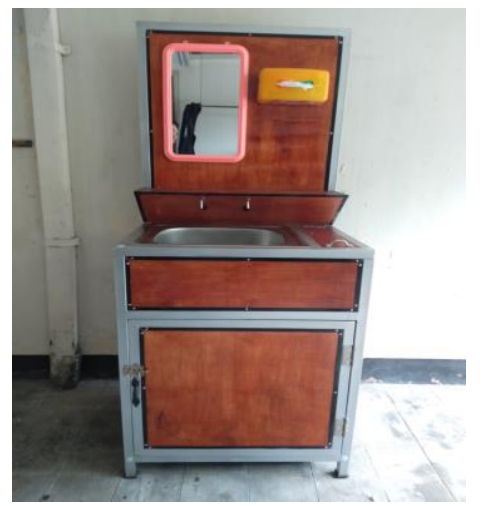

Gambar 4. alat automatic indoor handwasher

Alat handwasher otomatis indoor ini memiliki keunggulan adalah bisa digunakan pada dalam ruangan dan bisa mudah dipindah tempat. Disamping itu alat ini menghemat listrik karena sudah menggunakan batere rechargeabble. Dimensi alat ini adalah panjang, lebar dan tinggi 70x50x170 cm ergonomis dalam pengoperasiannya. Pengoperasiannya cukup dengan meletakkan tangan dibawah pipa cuci tangan, maka sensor infra red akan mendeteksi dan menyalakan pompa air. Terdapat pipa air untuk aliran air dan pipa air untuk sabun. Sedangkan untuk mematikan pompa air, cukup dengan menjauhkan tangan 
dari pipa cuci tangan tersebut. Konstruksinya menggunakan bahan besi hollow dengan kombinasi stainless steel sehingga kuat tapi ringan dan tahan air. Perawatan alat ini relatif mudah karena cukup mengganti air bersih dan air buang cuci tangan dari bak air yang dibagian bawah. Untuk perawatan kelistrikan cukup dilakukan mengisi batere sama seperti dalam penggunaan handphone cukup 2 kali dalam sehari selama 30 menit.

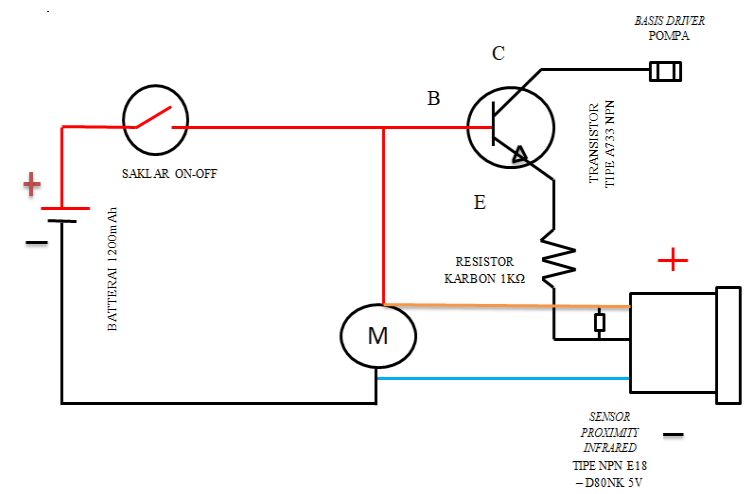

Gambar 5. wiring automatic indoor handwasher

Alat ini memiliki rangkaian kelistrikan seperti gambar diatas, bahwa tombol on ditekan, sehingga arus baterai mengalir menuju transistor. Transistor digunakan untuk memperkuat arus yang mengalirkan semua komponen dan sebagai pemutus dan penghubung aliran arus listrik (saklar). Kemudian arus menuju ke basis driver modul pompa yang berfungsi sebagai kendali untuk mengaktifkan dan mematikan pompa. Pada saat sensor deteksi mendeteksi halangan arus yang menuju sensor, makaakan memberikan sinyal ke basis driver pompa untuk mengaktifkan pompa. Tetapi arus dari sensor akan dihambat oleh resistor agar saat sensor tidak ada halangan sensor tidak langsung mengaktifkan pompa. Sehingga secara otomatis pompa akan aktif jika sensor terhalang oleh objek dan saat tangan mendekat sensor akan mendeteksi dan mengaktifkan pompa air secara otomatis keluar sesuai deteksi sensor. Karena pada dasarnya pompa galon elektrik ini satu saklar untuk mengaktifkan dan menghidupkan pompa sehingga perlu penambahan resistor dan transistor sebagai komponen pendukungnya.

Menurut I. Saputro [6], pembuatan alat pencuci tangan ini bertujuan untuk mencuci tangan tanpa memutar kran air. Perakitan kelistrikan ini menggunakan metode sensor deteksi yang mendeteksi gerak tangan. Air keluar secara otomatis sesuai dengan gerakan tangan dan menggunakan metode Ortogonal Array untuk mengetahui tingkat keefektifitas air yang dikeluarkan di tiap satuan waktu. Hasil keefektifitas air yang dikeluarkan pada alat pencuci tangan otomatis berdasarkan waktu tercepat 1.03 detik dan volume terbanyak sebesar $503 \mathrm{ml}$ pada percobaan pengujian A2B2CI (sensor berada di dalam ruangan, pompa berada di tengah dan volume bak penampungan dalam kondisi penuh). E.R. Ambarwati [7], menyatakan bahwa minat orangtua dan siswa untuk menerapkan mencuci tangan sangat besar, sehingga penyuluhan tersebut mudah diterima dan dapat menciptakan sikap yang positif terhadap pesan yang disampaikan yang mempengaruhi perilaku orangtua dan siswa. D.Subintarti [8], menunjukkan bahwa sistem mampu mengisi air ke dalam gelas hingga $1 \mathrm{~cm}$ sebelum mulut gelas dengan error terbesar $1,2 \mathrm{~cm}$ dan dapat menghentikan pengisian air sewaktu-waktu ketika tombol stop ditekan. Hasil pengujian juga menunjukkan bahwa suhu air panas dapat dikontrol sebesar $80^{\circ} \mathrm{C}$. 


\section{KESIMPULAN}

Berdasarkan hasil kegiatan pengabdian masyarakat diatas, dapat diambil simpulan sebagai berikut :

1. Alat automatic indoor handwasher ini sering digunakan di pendopo kelurahan kratonan, sehingga mampu meningkatkan produktifitas kegiatan kemasyarakatan terutama PKK dan Kti menuju kemandirian kampung sehat.

2. Kegiatan ini mampu menciptakan teknik lebih baik dalam pengelolaan media fluida air sebagai sumber kehidupan sehat.

\section{UCAPAN TERIMA KASIH}

Ucapan terima kasih kepada LPPM STTW Surakarta yang telah memberikan dukungan dalam pelaksanaan kegiatan ini secara lancar. Terima kasih atas partisipasi aktif kepada semua civitas akademika dan pihak mitra binaan Kti dan PKK Kelurahan Kratonan kecamatan serengan kodya surakarta.

\section{DAFTAR PUSTAKA}

[1] Peraturan Presiden Republik Indonesia Nomor 99 Tahun 2017, Gerakan Pemberdayaan dan Kesejahteraan Keluarga, Menteri Hukum dan Hak Asasi Manusia republik Indonesia, November, 2017

[2] WHO, Save Lives, Clean Your Hands, World Health Organization, 2010

[3] E.C. Halim, O. Soedirham, Perilaku Cuci Tangan di Kalangan Siswa-Siswi SMAK Santa Agnes Surabaya, The Indonesian Journal of Public Healt, FKM UNAIR Surabaya, Vol 13, No 2, hal 208-2019, Desember 2018.

[4] G.Danel, Otomatisasi Keran Dispenser Berbasis Mikrokontroller AT89S52 Menggunakan Sensor Foto dioda dan Sensor Ultrasonik Ping, Jurnal Fisika Universitas Andalas, Vol 1 No1, ISSN 2302-8941 pp.60-65, 2012.

[5] A.H.P. Mawuntu, Evaluasi Efektifitas Prosedur Cuci Tangan Pada Operator Fungsi Lumbal di Bagian Neurologi RSUP.R.D Kandau Manado, Jurnal Sinaps, Universitas Sam Ratulangi, Manado, Vol.1, No.1 (2018), hal 47-66, 2018.

[6] I. Saputro, Efektifitas Penggunaan Pompa Air Menggunakan Arus Listrik DC pada Automatic Handwasher, Tugas Akhir Diploma 3 STTW Surakarta, Agustus 2020.

[7] E.R.Ambarwati, Prihastuti, Gerakan Masyarakat Hidup Sehat (Germas) Mencuci Tangan Menggunakan Sabun dan Air Mengalir Sebagai Upaya Untuk Menerapkan Perilaku Hidup Bersih dan Sehat (Phbs) Sejak Dini, Jurnal Celebes Abdimas, LLdikti kopertis 9, Vol 1, No, 1, hal 45-52, April 2019.

[8] D.Kusbintarti, Dispenser Pengisi Gelas Otomatis menggunakan Sensor Ultrasonik dan Sensor Posisi Resistif, Publikasi Jurnal Skripsi Fakultas Teknik Universitas Brawijaya Malang, 2014. 